\section{Self-expression and family values: how are they related to marriage, divorce, and remarriage?}

\author{
Maria Carolina Tomás*
}

\begin{abstract}
CHERLIN, Andrew J. The marriage go-round: the state of marriage and family in America today. New York: Vintage Books, 2009. 271 pages. ISBN: 978-0-307-38638-0.
\end{abstract}

Decreasing marriage rates and increasing cohabitation and divorce rates seem to be a widespread phenomenon in Western countries. Many researchers claim that the family is losing its meaning and importance in society (i.e: STACEY, 1998). Others claim that union formation has not lost its significance, and if we consider cohabitation and marriage together, the total union rate is quite constant over time (FISCHER; HOUT, 2006; BUMPASS et al.,1991). Moreover, as Edin and Kefalas (2005) have shown, poor women postpone marriage not because they prefer to cohabit and/or have children before marrying, but because they value marriage as much as middle class women. Therefore, they have some minimum standards that they need to meet along with their partners, before committing themselves to a long-term relationship.

Americans have one of the highest marriage rates and one of the highest divorce rates, compared to other developed countries in the West. Cherlin, in his book The marriage go-round: the state of marriage and family in America today, came up with an original explanation for this apparent paradox in the United States. His argument is that Americans value marriage and family formation, and that is why they continue marrying. However, they also value individualism, which implies that a person has the right to end a marriage if $\mathrm{s} /$ he does not feel happy anymore. He states that Americans are constantly evaluating their situation and looking to fulfill their desire for self-expression and satisfy their self-esteem. Therefore, once married, Americans continuously ask themselves if the relationship is fulfilling, otherwise they feel that it should end. The competition between a strong support for marriage and the postmodern penchant for selfexpression and personal growth creates short relationships and frequent transitions between marital statuses: married, divorced, and (re)married. One striking statement in the book is that "children living with two married parents in the United States have a higher risk of experiencing a family breakup than do children living with two unmarried parents in Sweden" (p. 3).

At first glance, Cherlin's argument seems to be similar to the concept of the Second Demographic Transition (see LESTHAEGHE, 2007), but upon closer reading, we notice that his arguments delve more deeply into the concept of individualism. He explains the historical origins of the value of marriage and individualism, and how they changed over time (chapters two to four), therefore individualism is not something new and contradictory to family ideals and even to religion. He also stresses the importance of religious and legal institutions that reinforce the American view and behavior towards family life.

As described by the author, marriage in the U.S. changed its function from economic security, family alliance, religious commitment, and the model in which the husband is the breadwinner, to one based on companionship, and more recently (19602000 ) to what he calls individualized marriage. Individualized marriage is the concept that marriage is a partnership between two

* PhD Student in Sociology and Demography at University of California, Berkeley. Capes/Fulbright Fellow. 
individuals, in which each person has his/her own choices and is focused on his/her own self-expression. Historically this process was achieved by changes in values and family laws that limited the power of the husbands, supported working wives and mothers, and facilitated divorce (chapter 4).

In addition, marriage is seen as a relationship with emotional and personal rewards, in which people seek companionship, love, and self-development, and which is not necessarily centered on raising children and having community benefits. The author cites a very good example of how marriage is becoming a personal achievement; he states that wedding ceremonies in the past used to be paid by the families and had a symbolic meaning of acceptance of the new member and it was also a way to form family alliances. Today, more and more couples are planning and paying for the ceremony by themselves, and making the event a celebration of their personal achievement (chapter 5). He also explains how cohabitation and divorce began to be more common, transforming marriage into something optional and more vulnerable.

In Cherlin's argument, religion and laws have an important role in shaping family relations. Religion provides reasons for the importance of marriage and justification for divorce. And laws provide the mechanism in which marriage can be valued and divorce can be implemented. Therefore, throughout the book, Cherlin shows how religion and laws in the United States support both marriage and individualism. One could think that individualism and postmodern ideas would lead to lower church attendance and religious affiliations, however the author shows that Americans have a high rate of church attendance (60\% in 1999 to 2002 World Values Surveys). The only other Western country with higher church attendance than the United States was Ireland (67\%) (p. 103-4).

Cherlin explains that in the United States, religion "became a site for self-development - a place where you could continue to 'learn and grow' (...). Rather than inheriting your faith from your forefathers, you were free to choose your own, through a process that might involve exploring several churches" (p. 108). Religions have also become more tolerant of divorce nowadays, and some even encourage remarriage (chapter 5). "[Religious Americans] get divorced not because religion tells them that divorce is good, but because it tells them that selfdevelopment is good and that if they divorce, they will be forgiven and cared for" (p. 134$5)$. Therefore, religion, has also become a sphere where self-expression is important, instead of discouraging individualism.

In terms of laws, the author argues that the American family law values marriage, giving married couples privileges, such as the ability to file joint taxes. Moreover, the United States is the only country among Western developed countries where the government invests money on pro-marriage campaigns and public policies. Pro-marriage policies that provide incentives for young adults to marry have been proposed as a way to keep single-parent families out of poverty and maximizing children's wellbeing.

Something that also changed was the possibility of getting a good job without a college degree. Men without a four-year college degree have been affected the most by globalization and automation. Unlike their parents, they cannot afford the American dream and have become less marriageable. Consequently, there is a higher level of cohabitation and more unstable marriages among them, which leads to higher divorce rates due to their financial insecurity. However, like the author highlights, the idea of individualized marriage is common in all groups, as working and middle-class women and young adults have come to think that money is not the only factor for marriage. They also want the benefits of the individualized marriage: emotional support, opportunities for personal growth, and a more egalitarian relationship.

So, what actually has happened with the family in the United States? In summary, there was an unprecedented decline of marriage as the only acceptable arrangement for having sexual relations and for raising children. Therefore, marriage is still important, but it is optional. Marriage and family life have become matters of personal choice to the 
extent that would have astounded Americans in the 1950s.

Then, why is marriage still so relevant? The author suggests that "(...) although the practical importance of marriage has declined, its symbolic importance has increased" (p. 139). If in the past, marriage was considered a required transition, today it means a step that can be taken only after certain standards have been met: "[w]hereas marriage used to be the foundation of adult life, now it is often the capstone" (p. 139).

In the conclusion (Slow Down), the author highlights that Americans hold both cultural models, and these values seem to be held by all Americans, regardless of race, education, and religious background. Although he recognizes that some differences between groups exist, he thinks that they are not due to different cultural models. He states that "[a]lthough observers sometimes try to divide the population into traditional conservatives and postmodern liberals, those labels are inaccurate, except perhaps at the extremes" (p. 183). Another point of the conclusion that is worth noting is his advice about marriage: Slow down to start a new relationship and have children with a new live-in boyfriend. The priority of public policies should be to provide stable families to children and not ask women to marry because the majority of these relationships are very likely to end. A way to slow down the process is providing financial support to single parents, although there are many political barriers to providing cash assistance. Another way that he does not emphasize, but that follows the same line of argument, is to improve the enforcement of child support regulation, so an ex-partner would continue to help the child financially.

Leaving aside the historical and statistical specificities of the United States, could we use this framework to understand what is happening with family in other countries? In Brazil, for example, it seems that some apparent contradictions exist as well. Analyzing data from the World Value Survey (1991, 1996, and 2006), we find that Brazilians do value marriage; $71 \%$ disagreed with the sentence "Marriage is an out-dated institution" in 1991, 69.4\% did in 1996, and
$78.2 \%$ did in 2006. Hence, it appears that marriage is more valued in 2006 than in the early 1990 s. We also think that a "Child needs a home with a father and a mother". Eightyeight percent of the interviewees agreed with this sentence in 1991, 86.9\% did in 1996, and $81.50 \%$ concurred with the sentence in 2006. Although the proportion of people who agreed to the statement declined, the decrease is not large in a period of 15 years, and the majority of the population still agreed to the statement.

On the other hand, analyzing marriage data from the United Nations, we find a decrease in marriage rates (from 7.0 in 1980 to 4.7 in 2006) and an increase in divorce rates (from 0.3 in 1985 to 0.9 in 2006). The percentage of married women also decreased between 1970 and 2000 from $64.1 \%$ to $53 \%$, and the proportion of women in cohabiting relationships increased from $4.6 \%$ to $17.4 \%$ in the same period. It is worth highlighting that considering both rates together, union formation had similar levels between 1970 and 2000.

Do Brazilians also value marriage, but are conflicted with individualism? Is marriage going around in Brazil? Or is our history different? Are we moving toward a more Individualized Marriage Model? These are important questions to be considered for future researchers, and empirical hypotheses to be tested using Cherlin's approach.

Last but not least, it is important to consider whether or not the adoption of the two cultural models (marriage and individualism) is consistent across all socioeconomic, racial groups in Brazil, as it seems to be in the United States. Or has the transmission of these values differed by various groups in Brazil? This is a very important point since poor women have lower rates of marriage, higher rates of single parenthood and cohabitation. As Edin and Kefalas (2005) showed it is not because they do not value marriage. Analyzing data for the World Value Survey for the year 2006, we observe that $85 \%$ of lower class respondents agreed with the statement that "A child needs a home with a father and a mother", as did $79.9 \%$ of working class interviewees and $80.5 \%$ of middle-class respondents. The 
response rate is very similar for middle-class, working-class and lower-class, actually a little higher among lower class, indicating that perhaps there is no class difference in terms of family values.

Cherlin's argument is a counter-point of the argument that marriage is losing value in society, and that postmodern values are taking over family life. His argument that both cultural models are valued by mostly

\section{References}

BUMPASS, L.; SWEET, J. A.; CHERLIN, A. The role of cohabitation in declining rates of marriage. Journal of Marriage and the Family, v. 53, n. 4, p. 913-927, 1991.

EDIN, K.; KEFALAS, M. Promises I can keep: why poor women put motherhood before marriage. Berkeley and Los Angeles: University of California Press, 2005.

FISCHER, C. S.; HOUT, M. The family in trouble? Since when? For whom? In: TIPTON, S. M.; WITTE JR., J. The family transformed: religion, values, and society in American life. Washington DC: Georgetown University Press, 2005.

LESTHAEGHE, R. Second demographic transition. In: RITZER, G. (Ed.). Encyclopedia of Sociology. Blackwell, 2007, p. 4.123-4.127. all young adults (regardless of class, race, and religion) and that other institutions, like religion and law, reinforce this dual value system might change our views about family life in Brazil too. There are many open questions and testable hypotheses for future research to consider. On the other hand, it is important to consider the Brazilian historical, religious, and legislation specificities.

STANCEY, J. Brave families: stories of domestic upheaval in Late-Twentieth Century America. Berkeley: University of California Press, 1998.

UNITED NATIONS POPULATION DIVISION. World population prospects: the 2008 revision, 2009.

WORLDVALUES SURVEY. 1981-2008 Official Aggregate v. 20090901. World Values Survey Association (www.worldvaluessurvey.org). Aggregate File Producer: ASEP/JDS, Madrid, 2009.

Recebido para publicação em 01/10/2010 Aceito para publicação em 05/10/2010 